\title{
DEFENDANT'S WAIVER OF DOUBLE JEOPARDY BY APPEALING CONVICTION FOR A LESSER INCLUDED OFFENSE*
}

Although jeopardy has attached in a prior trial, ${ }^{1}$ a defendant's conduct may imply a waiver of his constitutional protection against double jeopardy. ${ }^{2}$ Thus, a second prosecution for the same offense may be allowed after arrest of judgment on defendant's motion, ${ }^{3}$ after discharge of the jury with his consent, ${ }^{4}$ or following a trial or appellate court's grant of his request for a new trial. ${ }^{5}$ In cases involving a new trial after reversal of conviction for a lesser included offense, ${ }^{6}$ the waiver doctrine poses a difficult question of whether defendant may be retried for the greater offense. For example, when a defend-

*Green v. United States, 236 F.2d 708 (D.C. Cir. 1956), cert. granted, 25 U.S.L. WEEK 3153 (U.S. Nov. 19, 1956) (No. 589).

1. Most jurisdictions hold jeopardy attaches when a jury is empaneled to try defendant on a valid indictment in a court of competent jurisdiction. See, e.g., Kepner v. United States, 195 U.S. 100, 128 (1904); Cornero v. United States, 48 F.2d 69 (9th Cir. 1931). See also Note, 24 Minn. L. REv. 522, 524-27 (1940). The rule, however, is not without exceptions in cases involving "unforeseeable circumstances that arise during a trial making its completion impossible, such as failure of a jury to agree on a verdict." Wade v. Hunter, 336 U.S. 684, 689 (1949). Some jurisdictions hold jeopardy attaches only when a verdict of acquittal or conviction has been rendered. See ALI, AdarInIstration of Criminal. LAW : Double Jeopardy 66-68 (1935) (collecting cases) (hereinafter cited as ALI DRAFT).

2. The federal provision reads: "[N] ${ }^{Y}$ or shall any person be subjected for the same offense to be twice put in jeopardy of life and limb." U.S. Const. amend. V. Thirty-five state constitutions contain similar double jeopardy clauses. Seven other states provide that no person "after acquittal" shall be again prosecuted for the same offense. One state bars a second prosecution after "acquittal or conviction." In five states there is no constitutional provision on the subject. See ALI DRAFT 7, 62-63 (collecting state constitutional double jeopardy provisions).

On waiver of objection to a second jeopardy see, generally, 1 Bishop, Crininal Law $\$ 998$ (9th ed. 1923); Mirler, Criminal Law \$ 186(e) (1934).

3. Ex parte Lange, 85 U.S. (18 Wall.) 163, 174 (1873); Wharton, Crminal Law 566 (12th ed. 1932); ALI DRAFT 106.

4. Se'e cases cited, ALI Draft 85.

5. State $e x$ rel. Francis v. Resweber, 329 U.S. 459,462 (1947) ; United States v. Ball, 163 U.S. 662, 672 (1896).

6. Recognized at common law, the lesser included offense concept derives from the fact that many crimes are combinations of other acts, each of which is a separate crime itself as well as a constituent part of the greater crime. If the prosecution fails to prove any element of the greater crime charged, the jury, following the court's instructions, may convict for the lesser offense established by the remaining elements. See State v. Harvey, 119 Ore. 512, 249 Pac. 172 (1926); ALI Moder Penal Code $\$ 1.08(4)$ (April 1956 Draft). Some jurisdictions have incorporated the rule into statute. E.g., FED. R. CRIM. P. 31 (c) ; N.Y. CODE CRIM. P. $\$ \S 444-45$. Crimes having lesser included offenses include robbery, felonious assault, arson and murder. See, generally, SNYDER, CRIMrrarar Justice 206-08 (1953). 
ant has been convicted of manslaughter under a first degree murder indictment but is granted a new trial, may the second trial convict for first degree murder or must it be limited to the lesser crime of manslaughter? Courts' divergent answers to this and similar questions reflect the clash between double jeopardy principles and an attitude that conviction of a lesser included offense should not foreclose the prosecution from proving greater guilt at a new trial after reversal.

Two conflicting views exist on the extent of defendant's waiver of double jeopardy protection in such cases. Roughly half the jurisdictions adhere to the common law rule of limited waiver. ${ }^{7}$ Under this rule conviction of a crime of lesser degree than the indicted offense operates as acquittal by implication of the greater offense. The implied acquittal bars retrial for the greater crime. ${ }^{8}$ Thus, by seeking review, defendant waives double jeopardy protection only as to that part of the verdict from which he appeals, conviction for the lesser crime. ${ }^{9}$ Courts adopting this view contend that by taking an appeal defendant should not be considered to have rejected the immunity from further prosecution conferred by an implied acquittal of the more serious crime. ${ }^{10}$ In addition to enforcing this common law rule, some of these courts declare that a broader waiver doctrine permitting retrial for the greater offense violates state constitutional double jeopardy provisions. ${ }^{11}$ This constitutional objection sometimes leads courts to adopt the limited waiver doctrine even in the face of statutes expressly providing for complete reopening of a case on grant of a new trial. ${ }^{12}$

7. See, $c . g$., Thomas v. State, 255 Ala. 632, 636, 53 So. 2d 340, 342 (1951) ; Hearn v. State, 212 Ark. 360, 205 S.W.2d 477 (1947) ; Ex parte Williams, 58 N.M. 37, 43, 265 P.2d 359, 363 (1954) ; ALI DraFT 123-25 and Note, 71 U.S.L. Rev. 421 (1937) (collecting cases). See also Trono v. United States, 199 U.S. 521, 540 (1905) (dissenting opinion), citing seventeen states which employ the limited waiver doctrine and declaring it to represent "the overwhelming weight of American decided cases."

8. E.g., Hearn v. State, 212 Ark. 360, 205 S.W.2d 477 (1947) ; Johnson v. State, 27 Fla. 245, 9 So. 208 (1891) ; People v. Cignarale, 110 N.Y. 23, 31, 17 N.E. 135, 142-43 (18S8). See 4 Blackstone, Commentaries $* 336$.

9. "His application for a correction of the verdict is not to be taken as more extensive than his needs. ... The waiver is construed to extend only to the precise thing concerning which the relief is sought." People v. Dowling, 84 N.X. 478, 484 (1881).

10. Ibid.; Trono v. United States, 199 U.S. 521, 538-39 (1905) (dissenting opinion).

11. E.g., State $e . t$ rel. Landis v. Lewis, 118 Fla. 910,160 So. 485 (1935); State v. Reed, 39 N.M. 44, 39 P.2d 1005 (1934).

12. Some states have provided by statute or constitutional amendment that grant of a new trial places defendant in the same position as if no earlier trial had taken place. See ALI DRAFr 116-19 (collecting statutes). A Supreme Court dictum in Kring v. Missouri, 107 U.S. 221, 225 (1882), upholds a state's right to abolish the common law concept of implied acguittal and limited waiver by such provisions. Cf. People v. Palmer, 109 N.Y. 413, 17 N.E. 213 (1888) (statute abolishing doctrine upheld against double jeopardy attack). Nevertheless, in some states courts have precluded on constitutional grounds the application of these statutes to a retrial on the greater offense after conviction for the lesser. Johnson v. State, 29 Ark. 31, 45-46 (1874) ; State v. Harville, 171 La. 256, 261, 130 So. 348,350 (1931). 
Other jurisdictions apply a theory of absolute waiver of double jeopardy protection. ${ }^{13}$ By seeking review of conviction for the lesser offense, these courts conclude, the defendant waives the protection that acquittal of the higher crime otherwise afforded him. ${ }^{14}$ In holding that a new trial for the greater offense after reversal of conviction for the lesser does not violate constitutional prohibitions against double jeopardy, they consider the verdict at the first trial an indivisible entity ${ }^{15}$ in taking an appeal a defendant cannot stand on part of the verdict, repudiating the rest. ${ }^{16} \mathrm{~A}$ new trial thus reopens the whole controversy. The Supreme Court adopted this view in Trono $v$. United States, a split decision rendered over fifty years ago. ${ }^{17}$ And recently in Green v. United States the Court of Appeals for the District of Columbia reasserted the absolute waiver doctrine. ${ }^{18}$ The court upheld a first degree

13. See ALI DRAFT 119-23 and Annot, 59 A.L.R. 1160 (1929) (collecting cases). See also ALI Model Penal Code $\$ 1.09$ (1) (April 1956 Draft) (conviction of lesser offense which is set aside is not an acquittal of greater inclusive offense).

14. Trono v. United States, 199 U.S. 521, 534 (1905) ; Brantley v. State, 132 Ga. 573, 575,64 S.E. $676,677(1909)$.

Other theories have been suggested to permit retrial on the greater offense in such cases. See Bailey v. State, $26 \mathrm{Ga} .579,581$ (1858), reasoning that if the conviction for the lesser offense which supports the implied acquittal of the greater is set aside, nothing remains to sustain the implied acquittal. Another view interprets the finding on a degree of an offense as only incidental to the fact that an offense has been committed. Thus, "if the finding as to the main fact be set aside, the finding as to the circumstances necessarily goes with it." State v. Behimer, 20 Ohio St. 572,578 (1870).

15. Trono v. United States, 199 U.S. 521, 531-32 (1905) ; Bohanan v. State, 18 Neb. 57, 61, 24 N.W. 390, 392 (1885) ; State v. Behimer, 20 Ohio St. 572, 578 (1870).

16. "When at his own request [defendant] ... has obtained a new trial he must take the burden with the benefit, and go back for a new trial on the whole case." Trono v. United States, 199 U.S. 521, 534 (1905).

17. 199 U.S. 521 (1905). In effect Trono extended the doctrine of United States v. Ball, 163 U.S. 662 (1896), which upheld double jeopardy waiver upon new trial for the offense of which defendant was previously convicted, to include the offense of which at common law he was impliedly acquitted. See text at note 8 supra.

In Trono defendant had been tried for murder in the Philippine Islands by a magistrate without a jury. Convicted of assault, he appealed to the Supreme Court of the Philippine Islands. That court set aside the assault conviction and found defendant guilty of second degree murder. The United States Supreme Court affirmed in a five-to-four decision, Justice Holmes concurring only in the result. 199 U.S. at 535. Justice Holmes was unsympathetic to the concept of former jeopardy. Cf. Mencken, Mr. Justice Holmcs, in The Vintage Mencken 185, 195-97 (Cook ed. 1956). One year prior to Trono he had dissented from a decision that federal prosecutors could not appeal in a criminal case. He reasoned that "a second trial in the same case must be regarded as only a continuation of the jeopardy which began with the trial below." See Kepner v. United States, 195 U.S. 100,137 (1904).

18. 236 F.2d 708 (D.C. Cir. 1956), cert. granted, 25 U.S.L. WEEK 3153 (U.S. Nov. 19, 1956) (No. 589). Green marks the first time that Trono has been followed by a federal court of appeals in a case arising within United States territorial limits to abrogate the common law limited waiver doctrine. Previously, the Supreme Court's decision was followed for this purpose by a court of appeals in but one case-a proceeding arising from Puerto Rico. See Carbonell v. People, 27 F.2d 253 (1st Cir. 1928) (manslaughter 
murder conviction on retrial after having previously reversed the original conviction for the lesser included offense of second degree murder. ${ }^{19}$

The absolute waiver doctrine thwarts double jeopardy principles. Although the Trono line of decisions considers the verdict at the first trial a single entity, ${ }^{20}$ that verdict clearly operates in a dual capacity while it stands unreversed. ${ }^{21}$ It serves as a conviction for the lesser offense and, according to traditional double jeopardy doctrine, as a bar to a new prosecution for the greater offense. ${ }^{22}$ Thus, the absolute waiver theory rests on a legal fiction

conviction did not bar prosecution for murder at new trial after reversal). Carbonell may not be significant, since the Puerto Rican Code of Criminal Procedure had specifically abolished the limited waiver doctrine. Id. at 254. One district court, however, has applied Tront's absolute waiver doctrine in a case arising in the United States. See United States v. Gonzales, 206 Fed. 239 (W.D. Wash. 1913). No federal case found has adopted a limited waiver rationale.

19. Five of the nine judges sitting en banc thought the Trono doctrine should be extended to a case arising in the United States. Concurring, one judge saw "no escape in this case from the law there laid down." 236 F.2d at 715. The three dissenters thought the court "should apply the prevailing rule at common law which would have precluded [defendant's] second trial for the greater offense of which he had been acquitted." Id. at 718. They distinguished the procedures operative in a federal court in the United States from those applicable in the Philippines "which permitted the whole case to be reviewed and tried de novo in the appellate court." Ibid. Since the Supreme Court in Trono said it considered the case "the same as if it arose in one of the Federal courts in this country," such distinction seems a tenuous ground on which to avoid application of absolute waiver. Sce 199 U.S. at 530.

Two other issues were raised in Grcen. Defendant's first argument that the unappealed conviction for arson barred a subsequent trial for felony murder was rejected by resort to the traditional "act-offense" dichotomy and "same evidence" tests. 236 F.2d at 712-13. See People v. Andrae, 305 IIl. 530, 137 N.E. 496 (1922) (acquittal of first degree murder, killing during course of robbery, held not to bar subsequent prosecution for burglary) ; Commonwealth v. Crecorian, 264 Mass. 94, 162 N.E. 7 (1928) (same). Contra, State v. Cooper, 13 N.J.L. 361 (Sup. Ct. 1833). Secondly, defendant's contention that statements elicited while in hospital custody for two days prior to arraignment were inadmissible under the $M c N a b b$ rule, $M[c N a b b$ v. United States, 318 U.S. 332 (1943), was also rejected by the majority. But two dissenting judges found the second argument persuasive. 236 F.2d at 715 .

20. See text at note 15 supra.

21. A further argument against viewing the verdict as a single entity is suggested in Johnson v. State, 27 Fla. $245,271,9$ So. 20 \&, 212 (1891). In rejecting the concept, the court concluded: "Otherwise, if three be indicted together for the same murder as principals, and two were acquitted, and the third convicted, the two acquitted would have to be retried upon a new trial granted to the convict, because the verdict was a unit." Such a result was declared unconstitutional in United States v. Ball, 163 U.S. 662, 671 (1896).

22. The Court stated in Trono v. United States, 199 U.S. 521, 535 (1905): "As the judgment stands before he appeals, it is a complete bar to any further prosecution for the offense set forth in the indictment, or of any lesser degree thereof." It is generally also agreed that trial on an indictment solely for a lesser offense will bar a new trial on a greater degree of the same offense, since the new trial would again put defendant in jeopardy on the lesser count. People v. MicDaniels, 137 Cal. 192, 69 Pac. 1006 (1902); State v. Wiles, 26 Minn. 381, 4 N.W. 615 (1880). See Note, 24 MrNN. L. Rev. 522, 543$44(1940)$. Another reason for barring second prosecutions, whether the first trial is for 
created to overcome constitutional double jeopardy prohibitions against multiple prosecutions. As such it conflicts with that standard of fairness underlying double jeopardy which prevents the prosecution from retrying an accused for any single offense for which there has been an acquittal or an unappealed conviction. ${ }^{23}$ By use of the single entity rationale, absolute waiver in practice rejects this fundamental concept once an appeal is taken from conviction of a lesser included offense.

Such cases as Trono and Green appear to rest on largely unarticulated considerations which have been allowed to outweigh the importance of double jeopardy principles. ${ }^{24}$ The absolute waiver doctrine, it has been suggested, expresses judicial recognition that conviction of a lesser offense may represent not innocence of the greater crime, but rather jury leniency which should be rejected to allow the state another opportunity to "exact the full penalty."

the lesser or greater offense, is that the offenses may be considered mutually exclusive or alternative. Thus, defendant commits either murder or manslaughter, never both. Kirchheimer, The Act, The Offense and Double Jeopardy, 58 YALE L.J. 513, 516-17 (1949).

23. Cf. Peters v. Hobby, 349 U.S. 331, 344-45 (1955) ; Ex parte Lange, 85 U.S. (18 Wall.) 163,170 (1873). For a statement of the objectives of the constitutional prohibition against double jeopardy, see Comment, Statutory Implementation of Double Jeopardy Clauses: Nezo Life for a Moribund Constitutional Guarantee, 65 YALE L.J. 339, 340-41 (1956). Se'e also Lugar, Criminal Law, Double Jeopardy, and Res Judicata, 39 Iows L. REv. 317, 329-44 (1954) (availability of res judicata plea in criminal cases to supplement double jeopardy doctrine).

24. One commentator views repudiation of the "fiction of implied waiver" as essential to a realistic interpretation of double jeopardy problems. "This would lead to a frank recognition of the fact that the attaching of jeopardy under certain circumstances and its failure to attach under others has been determined to be desirable, because of considerations of public policy, which exist in criminal cases. ..." See Mirler, Crnmrnal Law 538 (1934).

The American Law Institute's Model Penal Code adopts, in effect, the absolute waiver doctrine. See ALI Model Penal Code $\$ 1.09$ (1) (April 1956 Draft). In support of its position it states: "Where [defendant] ... procures the reversal on the ground that his conduct, though it constitutes the greater offense, does not constitute the lesser offense, subsequent prosecution for the greater offense is certainly warranted." Id. at 49. This reasoning can only apply where defendant obtains reversal of his conviction for a lesser included offense on the ground that the lesser crime was improperly submitted to the jury. See note 38 infra and accompanying text. The Institute has apparently allowed one type of case, where absolute waiver seems justified, to control selection of a rule that would cause undue hardship in other situations.

25. See Gibson v. Somers, 31 Nev. 531, 534, 103 Pac. 1073, 1074 (1909), declaring that in many case's a jury agrees

"to bring in a verdict of a lesser degree of homicide, when, as a matter of right and justice, the defendant, if he got his just deserts, should be hanged by the neck until he be dead. The people of the State ... ought to be entitled to exact the full penalty of the law with equally as good a right as the defendant has to receive only the punishment provided by law for the lesser degree of crime, and to hold otherwise, we believe, would be a travesty of justice."

See also Note, 38 YALE L.J. 978, 983 (1929). 
A second factor favoring absolute waiver, asserted as a "practical, common sense rule," ${ }^{26}$ is that reversal of conviction for the lesser offense without right to retry the greater would be tantamount to complete acquittal whenever the prosecution's theory could not support a new conviction for the lesser offense. ${ }^{27}$

Grecn presents a situation highlighting these considerations. Defendant was indicted on two counts: (1) arson ${ }^{28}$ and (2) murder in the first degree committed in perpetration of arson. ${ }^{29} \mathrm{He}$ was convicted of arson and second degree murder and appealed only the second degree murder conviction. The District of Columbia Court of Appeals reversed for a new trial, declaring the trial court erred in giving a second degree instruction since "all the testimony as to what occurred in the burning house pointed to murder in the first degree and nothing else." 30 Since the government's case was based wholly on a first degree felony murder theory, which does not require proof of intent to kill, ${ }^{31}$ it probably could not establish guilt were the new trial limited to second degree murder. ${ }^{32}$ Consequently, reversal would likely be tantamount to acquittal.

26. Note, 23 Tur. L. Rev. 575, 576 (1949).

27. See, e.g., State v. Ash, 68 Wash. 194, 122 Pac. 995 (1912). Defendant was either guilty of first degree murder or entitled to acquittal by reason of insanity. None of the evidence justified a manslaughter conviction, but the jury received instructions on the lesser offense and convicted for manslaughter. The appellate court reversed, declaring the manslaughter instruction had been improperly submitted. Overruling earlier Washington cases and holding that defendant could be convicted for murder at a new trial, the court said:

"[T]o take the contrary view would mean that a murderer who admits his crime and whose only regret is that he was apprehended before his lust for killing was fully satisfied, as he sought a second victim, would be left free to pursue his criminal intent until he had added other victims to his score. ... We cannot control the verdicts of juries in their failure to make true deliverance between the state and the criminal, but we can refuse to extend the farce so as to make it operative as an absolute discharge."

Id. at 202-03, 122 Pac. at 998 .

28. D.C. CoDE $\$ 22-401$ (Supp. 1956).

29. Id. $\$ 22-2401$.

30. Green v. United States, 218 F.2d 856, 859 (1955).

31. D.C. CoDE $\$ 22-2401$ (1951) defines the felony murder here involved: "Whoever ... without purpose so to do kills another in perpetrating or attempting to perpetrate any arson . . . is guilty of murder in the first degree." (Emphasis added.)

32. See People v. Hoffman, 219 App. Div. 334, 220 N.Y. Supp. 249 (2d Dep't), aff'd, 245 N.Y. 558, 157 N.E. 869 (1927). But see Note, 66 YALE L.J. 427, 433 (1956) (suggesting that malice aforethought of the felony could sustain a conviction for second degree murder).

Courts applying the limited waiver doctrine generally hold the state is limited with respect to proof by the fact defendant may be convicted only of a lesser offense than that charged in the original indictment. See West v. State, 55 Fla. 200, 46 So. 93 (1908) (manslaughter conviction at first trial rendered admission in later trial of evidence tending to show premeditation reversible error). However, some courts have reasoned that "jeopardy" refers to punishment and not to charge and have allowed evidence tending to show the greater crime. See People v. McFarlane, 138 Cal. 481, 71 Pac. 568 (1903) (conviction of manslaughter upheld though only evidence indicated premeditated murder). 
Moreover, the jury found the essential elements of first degree felony murder when it convicted defendant at the first trial of arson and second degree murder. From the evidence presented this verdict necessarily included the finding that death resulted from the commission of arson. ${ }^{33}$ The second degree murder verdict was apparently an instance of jury leniency and not, under the circumstances, a sign of innocence of the greater offense. ${ }^{34}$

But the above considerations favoring absolute waiver are not always operative. For instance, a defendant may be indicted for first degree murder, convicted of manslaughter, and then secure reversal of the manslaughter conviction because of a prejudicial error of law in the admission of evidence. In such a case, the government should not be allowed a retrial for first degree murder. Reversal would not be tantamount to acquittal since no theoretical barrier exists preventing the government from a second manslaughter conviction if supported by the evidence. ${ }^{35}$ And since the error was in favor of the prosecution it could not have misled the jury, for its finding that the defendant was

This view led to an anomalous result in People v. Huntington, 8 Cal. App. 612, 616, 97 Pac. 760, 763 (1908). After reversing a conviction for the lesser included offense of manslaughter on the ground the trial court erred in giving the instruction when all the evidence pointed to first degree murder (death by criminal abortion), the court upheld a second manslaughter conviction on the same evidence. It declared defendant was not prejudiced by an instruction permitting him to be found guilty of manslaughter even if the evidence warranted conviction for murder. Cf. Barnett v. People, 54 III. 325, 331 (1870). On this latter theory the obstacle of a lack of evidence confronting an attempt to convict for the lesser offense, posed in the Green case, would apparently be overcome.

33. The court of appeals in reversing the original conviction concluded that the undisputed evidence "shows beyond peradventure that Bettie Brown's death was caused by the fire in the house in which her body was found." Green v. United States, 218 F.2d 856, 859 (D.C. Cir. 1955).

34. The jury can return a verdict "in the teeth of both law and facts" by convicting for the lesser included offense. See Horning v. District of Columbia, 254 U.S. 135, 138 (1920). But jury leniency as a "sovereign prerogative," see SNYDER, op. cit. supra note 6, at 206, is not without judicial limitations. See People v. Mussenden, 308 N.Y. 558, 563, 127 N.E.2d 551, 554 (1955) :

"[W] hile the jury has the power to refuse to find any fact regardless of how clearly it may appear to a judge to have been proved, the jury daes not . . . have the right to find a fact and then refuse to render the verdict which such a finding necessarily requires. . . . [T] he jury's power to dispense mercy, by favoring the defendant despite the evidence, should not be allowed so to dominate the trial proceedings as to impede or interfere with the jury's primary fact-finding function. The principle has, accordingly, evolved that the submission of a lesser degree or an included crime is justified only where there is some basis in the evidence for finding the accused innocent of the higher crime, and yet guilty of the lower one."

See note 38 infra.

The effect of holding that absence of evidence tending to reduce an offense precludes submission of lesser included crimes has been likened to a partially directed verdict for the state. See Note, 56 Colum. L. Rev. S88, 894 (1956).

35. Cf. note 27 supra and accompanying text. 
guilty of manslaughter could only mean that the evidence-even including that improperly admitted-did not satisfactorily establish guilt of the greater crime. ${ }^{36}$

A comparison of the facts in Green with those of the stated hypothetical suggests that the nature of the trial court's error for which reversal and a new trial is ordered should determine the extent of waiver of double jeopardy protection. The constitutional prohibition against multiple prosecutions and punishments is fundamental; it should not be eroded by indiscriminate application of doctrines which neglect the factors actually operative in different prosecutions. ${ }^{37}$ Mistakes of the trial court should not afford the government a second chance to prosecute for the greater crime unless the error requiring reversal of the lesser conviction necessarily also affected, to the government's prejudice, the jury's determination of innocence of the higher offense. Such an error is difficult to conceive except in a few cases involving improper submission of lesser included offenses. ${ }^{38}$ Thus, it could occur with an erroneous instruction to the jury permitting conviction of a crime which is not a lesser included offense of that charged in the indictment. ${ }^{39}$ Or, as in Green, the error could result from conviction of a lesser offense which, although covered in the indictment, is entirely unsupported by the evidence. ${ }^{40}$ In these cases erroneous submission of a lesser crime may deter the jury from returning a verdict for the higher offense, thus prejudicing the prosecution by providing an unwarranted alternative basis for conviction. Absent this alternative, the jury might have convicted for the greater offense in preference to complete acquittal. ${ }^{41}$ On the other hand, since the government may actually have lacked evidence of the greater offense sufficient to convict, it may be contended that no prejudice to the prosecution resulted from improper submission of the lesser offense. But whether improper submission prejudiced the prosecution in any instance is not susceptible of conclusive proof after the fact; decision on the scope of the new trial must be weighed in the light of this uncertainty. The alternative of a new trial limited to the lesser offense may be rendered ineffectual by the theoretical barrier where evidence is entirely absent to support

36. Cf. note 25 supra and accompanying text.

37. See note 24 supra.

38. Two conditions must be satisfied before a court may properly submit a lesser offense to the jury: (1) the evidence must justify a conviction for the lesser degree and (2) the indictment must set forth all the essential elements constituting the lesser offense. See State v. Meie, 140 Conn. 398, 401, 100 A.2d 570, 571 (1953) ; Bader, Lesser Included Crimes, 21 BROOKLYN L. REv. 75 (1954). But courts have placed varying interpretations on these general conditions. See Note, 56 Colum. L. Rev. 888 (1956).

39. See, e.g., In re Hess, 45 Cal. $2 \mathrm{~d} 171,288$ P.2d 5 (1955) (contributing to the delinquency of a minor not a lesser included offense of first degree rape) ; People v. Hoffman, 219 App. Div. 334, 220 N.Y. Supp. 249 (2d Dep't), aff'd, 245 N.Y. 558, 157 N.E. 869 (1927) (second degree murder not lesser included offense of felony murder where indictment negatives intent to kill).

40. See note 27 supra.

41. See People v. Mussenden, 309 N.Y. 558, 570, 127 N.E.2d 551, 558 (1955) (dissenting opinion). 
the improperly submitted lesser offense. ${ }^{42}$ And conviction of the lesser offense in any event evidences jury recognition of the criminal character of defendant's conduct. On balance therefore, society's interest in the punishment of crime would be best served in these cases by a retrial of the greater offense rather than one confined to the lesser which would often amount to complete acquittal.

Reasoning derived from the Supreme Court's decision in Palko v. Connecticut ${ }^{43}$ may support the proposed "nature of the error" test. Palko upheld against due process attack the right of a state to authorize appeal by its prosecutors in a criminal case.44 The decision treated the right as a "reciprocal privilege" to that of a defendant who obtains review of a trial "infected with error adverse" to him. ${ }^{45}$ The right of a government, either state or federal, to retrial of a greater offense because of errors a defendant raises against conviction for a lesser offense in a prior trial is in practical effect the same as a right of appeal; if successful, the latter also permits a second opportunity for conviction. Since in the federal courts the double jeopardy clause has been interpreted to prohibit government right of appeal from a criminal judgment, ${ }^{46}$ the right of the federal government to prosecute again by reason of error in a prior trial should be at least as narrowly circumscribed as the right of a state to appeal. Accordingly, Palko's due process requirement of "adverse error" for a state appeal should limit the right of both federal and state governments to retry for the greater offense after reversal of conviction for the lesser. The prosecution therefore should not have the right to retry for the greater offense unless conviction of the lesser is reversed on the basis of error which affected the whole trial adversely to the government's interests. ${ }^{47}$

42. See note 27 supra and accompanying text.

43. 302 U.S. 319 (1937).

44. See Conn. Gen. Stat. \$ 8878 (1949) and Wis. Stat. $\$ 358.12$ (1953) (state may appeal-not guilty finding if an error of law, prejudicial to the prosecution, was committed at trial).

45. 302 U.S. at 328 .

46. Kepner v. United States, 195 U.S. 100 (1904). United States v. Sanges, 144 U.S. 310,312 (1892), relied on by the Court in Kepner, contains a dictum indicating that a statute granting a right of appeal to the government might be upheld. But cf. Peters v. Hobby, 349 U.S. 331, 344-45 (1955).

47. See Justice Douglas' concurring opinion in United States v. Sapir, 348 U.S. 373 (1955), a recent decision concerning the propriety of a new trial after a conviction for the same offense had previously been reversed for lack of evidence. Justice Douglas concluded that a circuit court's grant of a new trial on the government's motion, after initially ordering dismissal of the indictment for lack of evidence, violated the Fifth Amendment double jeopardy protection. But he distinguished two situations in which a new trial after reversal for lack of evidence might have been appropriate. Citing Trono, he reasoned that if the defendant himself asks for a new trial "he opens the whole record for such disposition as might be just." Id. at 374. "Moreover," he continued, "a reversal by the appellate court on a ground of error that infected the trial would also be different as Palko v. Connecticut ... shows." Ibid. (Emphasis added.)

Concerning Justice Douglas' reference to Trono, it may be noted that defendant's appeal in Sapir sought reversal of his conviction but not a new trial. In Bryan v. United 
The "nature of the error" test should be adopted as a limitation on the absolute waiver doctrine. Waiver would be implied in cases in which it served as a constructive tool in the administration of justice, yet it would not be used to penalize the defendant for taking a justified appeal. ${ }^{48}$ This qualification of absolute waiver would thus serve society's interest in assuring punishment of crime without undermining basic safeguards against double jeopardy. ${ }^{49}$

States, 338 U.S. 552 (1950), a retrial after reversal for lack of evidence was declared "just and appropriate" where a "new trial was one of the remedies which petitioner sought." Id. at 560. Thus, if defendant's intent in appealing is to be the determining factor in weighing the propriety of a new trial after reversal of a conviction in chief, it could be argued the limited waiver doctrine would best effectuate that intent in an appeal from conviction for a lesser included offense. Under limited waiver, defendant's intent in appealing is realistically limited only to the part of the judgment which he regards as unjust. Sce Petition for Certiorari, p. 18, Green v. United States, 236 F.2d 708 (D.C. Cir. 1956), cert. granted, 25 U.S.L. WeER 3153 (U.S. Nov. 19, 1956) (No. 589). See also note 9 supra and accompanying text.

48. See Trono v. United States, 199 U.S. 521, 538 (1905) (dissenting opinion).

49. The extent of waiver poses a similar problem where defendant is granted a new trial after he has been convicted of some, but not all, the counts charged in the indictment. Some courts hold that the grant of a new trial reopens the whole case, permitting retrial on the counts for which there was an express or implied acquittal at the first trial. E.g., State v. Beal, 202 N.C. 266, 162 S.E. 561 (1932). See Annot., 80 A.L.R. 1114 (1932) (collecting cases). Most courts, however, limit the new trial to counts for which there have been a conviction. Id. at 1106. See 2 Cooley, Blackstone 498 n.15 (3d ed. 1884). In Burton v. United States, 202 U.S. 344 (1906), the Supreme Court expressly avoided extending the Trono absolute waiver doctrine to such a situation by finding that the count in question at retrial was different from that in the original indictment.

With multiple count indictments, defendant should not be required to waive acquittal on one count in order to gain retrial on another. The concept of the verdict as a single entity, see text at note 15 supra, cannot logically be extended to situations involving distinct crimes charged in separate counts. Unlike lesser included offenses, distinct crimes separately charged are not mutually exclusive or alternative. See note 22 supra. Cf. Dunn v. United States, 284 U.S. 390, 393 (1932). 